\title{
Communication Strategy of Garuda Indonesia to Achieve High Performance
}

\author{
Boedi Priantoro ${ }^{1}$, Prahastiwi Utari ${ }^{2}$ and Andre Rahmanto ${ }^{3}$ \\ \{boedipriantoro@student.uns.ac.id ${ }^{1}$, boedisma3@gmail.com ${ }^{1}$ \} \\ 1,2,3Universitas Sebelas Maret Surakarta, Indonesia
}

\begin{abstract}
Communication strategy becomes an important thing must be done by every industry today. This study describe the communication strategy of Garuda Indonesia Surakarta to achieve high performance. By using a descriptive qualitative approach, this study seeks to explore how communication strategy of Garuda Indonesia can be implemented by frontliner so that high performance can be achieved. This research was conducted at Garuda Office Surakarta. The data were obtained through interviews and in-depth observations. The results of this research, researcher concluded that communication strategy conducted by Garuda Indonesia Surakarta through the stage: Finding, keeping and growing which can only be done by making communication based on close relationship so that able to build good relationship, second communication strategy adapted to the conditions and culture of the society, third implementation of this Strategic communication planning giving an output of Garuda's sales achievement of $118 \%$ in 2018. This communication strategy can work well if done by reliable frontliner who has the skills to communicate and personal selling skills to create good relationship.
\end{abstract}

Keywords: Communication Planning, Strategy, Competition, Close Relationship

\section{INTRODUCTION}

The development of the Internet in Indonesia is very fast, this is marked by the very significant increase of internet users from 1998-2017. In 1998 internet users in Indonesia recorded 0.5 million people and in 2017 it had reached 143.2 million people (Kompas R \& D / DEW / TPN, APJII, Kompas, 30 January 2019).

The change of people's behavior that changes the entire process of interaction, business, transactions and the current human lifestyle. The world has no regional boundaries in terms of communication, trade, politics, social and culture. This era changed the entire order of human life and created behavioral changes in terms of decision making in terms of economics, business and finance. This very rapid change brings a difficult situation to predict, all sectors change very quickly. This situation is what business people call a situation of Volatility, Uncertainty, Complexity, Ambiguity or Abbreviated as VUCA [1]

This situation was introduced by the US ARMY as part of the leadership technique in dealing with uncertain situations on the battlefield. The meaning of volatility is a situation which is overwhelmed by uncertainty that is very vulnerable to a change, uncertainty is a 
situation that is filled with uncertainty and this situation is full of surprises due to a change and can occur at anytime and anywhere, complexity is a situation that there are very many obstacles that are very difficult and must be faced, ambiguity is a situation where there is confusion in the direction that has been determined. [2]

To achieve sales, revenue and route result targets, each Garuda Indonesia branch office both domestic and international, must compete with competitor airline on their route, online travel agent whose sales are recognized by head office. Actually, in the business airlines competition that actually has the same product, which is timetable, namely flight schedules, flights, number of seats. But the difference is the services of each airline. This is the advantages and disadvantages of an airline in selling its products. In this digitalization era, growth of the aviation market in Indonesia on averaged above $20 \%$ per year since 2000 (Directorate General of Civil Aviation, 2007) and changes flight deregulation so that it can change consumer behavior and also change competition, both between airlines and within ticket sales. [3]

Various strategies of PT. Garuda Indonesia Surakarta to win the competition are using differentiation and improving service values to achieve the goals of the company, by achieving performance branch office. In this case it is not only a marketing strategy to increase sales, but also in terms of communication links between frontliners and customers. Besides that, to be able to communicate well so that close relations can be established between the frontliner of Garuda Indonesia and its consumers, a frontliner must understand and have extensive insight into the communication behavior of the Surakarta community. In this interpersonal communication, a frontliner should place his position as a consumer, so that he can easily understand the intentions and messages conveyed by consumers. "The essence of mastering communication is the ability to associate multiple perspectives, where we understand the perspectives, beliefs, thoughts, or feelings of ourselves and others (Philips \& Wood, 1983). In committing to increasing interpersonal communication, frontliners also consider consumers to be unique individuals who have close relationships as if in one family. Julia T Wood (2013) states that in ethics in communicating each person is required to respect themselves and respect others not only based on their status or job [4]. According to Cavanaug and Lisa.A that close relationship with friends, clients, family and romantic partners are a primary source of meaning in consumer's lives and this close relationship influence consumers for deciding to eat, what to buy and influence consumer perceptions, decision and behaviour [5]. in addition to communicating frontliners can improve their soft skills and hard skills through courses, sharing season provided by company and is expected to be applied when providing 5 -star services to consumers.

In this case it is considered necessary to implement communication strategy so that it can help out the problems faced in these uncertain situations. The strategic communication that will be carried out by Garuda Indonesia's frontliner team, must be based on the behavior of Surakarta society. According to Dave Fleet that "Strategic communication planning consist of Context (set the scene, and prepare yourself), Enviromental scan (frame your analysis), Stakeholder Analysis (Getting Started), Objective (the target), Strategy, Audience (market segment), announcement, Message, Tactics, Issues, Budgeting, Evaluation" [6]. In the research of consumer behavior by Jeff Joireman and Kristina M Durante stated consumer behavior considers how phenomena such as attitudes, persuasion, social cognition, and self concept influence decision making [7].

Communication strategy of Garuda is implemented in service to its customers to achieve sales targets and there is growth from year to year. 
The effect of providing communication strategy by doing good interpersonal communication between frontliners and consumers of PT. Garuda Indonesia in Surakarta is expected to have an impact also on Word of Mouth Marketing to the entire Surakarta region. Where this marketing strategy is very fast and very practical and has a very strong impact.

This research is using qualitative approach and the aims to analyze the influence and impact of communication strategy implemented by PT. Garuda Indonesia's front liner on the achievement of the Performance.

The same research has been written by the Ngurah Putra and Ni Ketut Dimar Warsihantari. In their journal entitled Airasia and Malaysia Airlines crisis communication strategies: a content analysis. In this study revealed that communication strategies are used to manage the crisis in performing service recovery. [8]

Another similiar research has been done by Rounghua Zhang, in his journal entitled Research On Shaanxi Brand Communication Strategy Under New Media Environment. In his study explained Communication Strategy is not only provide opportunities for brand innovation, but can strengthen their media so that they can deal with new media . [9]

But in my research that Communication strategy is used to create close relationship that was expected to be able to improve Garuda Indonesia's performance. this is what difference from previous research which using communication strategy for service recovery in crisis management and for conducting brand innovation communication strategies. This research also provides input and guidance to managers in the airline industry to be able to carry out communication strategies by using methods of finding, keeping and growing to win the competition.

\section{METHOD}

This research was conducted at the Garuda Indonesia Branch Office Surakarta under Sales and Marketing Unit. The research using qualitative methods with the process of collecting data through observation, interviews, surveys, documentation to obtain a large variety of data. [10]

This study uses data analysis model Miles and Huberman, where qualitative research data analysis is carried out at the time of data collection takes place, and after completion of data collection in a certain period. At the interview session, if the researcher had conducted an analysis and that felt to be unsatisfactory, so the researcher would continue the question again, to some extent, obtained data that was considered credible.

\section{FINDINGS AND DISCUSSION}

The results of this study are the frontliners of Garuda Indonesia Branch Office Surakarta carrying out Strategic communication planning to improve the performance of Garuda Indonesia Surakarta. According to information from several informants from frontliners that basically they set this strategy for every consumer who came in the sales office in Surakarta City, but in communicating is still reflected the 5 star's standard service.

The results of research conducted by observation and interviewing with frontliner. Researcher could find several finding issues: first, Garuda Indonesia has implemented a communication strategy consist of three stages or phases in carrying out the communication. In each phase creates a momentum to be able to create consumer loyalty to all products offered by the Garuda Indonesia frontliner. By utilizing every momentum at every "touch point" of service, hospitality, courtesy, how to communicate from frontliners not only give an impression to their customers, but also can be a positive advocacy action carried out by 
consumers to others and can build a service brand for Garuda Indonesia branch office Surakarta.

The stages in building communication in order to create close relationships between Garuda's frontliner and their Consumers are: a) Finding, is a communication process when orienting to consumers, this is the process of forming communication relationships, for example: opening the door when consumers enter the Garuda's Office, giving greetings, smiling, interacting politely, provide solutions when consumers are full of doubts; b) Keeping, is a communication process that is a follow-up of the finding process that has the goal of strengthening communication between frontliners and consumers, so that a close relationship is formed, for example by doing: communication with the social media such as send birthday card email to customer, give notification if there is a flight delay (so that alternatives can be given) and also communication by WhatsApp, so if you have established convenience communication, customer are no longer coming to the Garuda office, but they will contact via cellular phones or WhatsApp media in to purchase ticket, frontliners of Garuda Indonesia Branch Office Surakarta is ready to help, even it's not office hours and wherever the customer is; c) Growing, in this process of communication strategy, frontliners who have integrity and loyalty are needed as militant frontliners, this is a follow up to the phase of keeping the expectations of consumers very high to their frontliners. This momentum is used by frontliners to make close relationships and communication strategy to create advocacy in giving positive comments to other about brand of Garuda. Mary Anne Fitzpatrick said that "family relationships create the reality of conversation-oriented communication behaviors symbolized by a close and warm relationship. To achieve this there are several cycles in building family relationships, they are: first cycle of relationship formation (orientation), second cycle, raising or strengthening relationships, and third cycle, developing relationships, encouraging closeness of relationships, strengthening relationships. [11]

Second, this communication strategy with "Finding, Keeping and Growing stage" is very effective to be used as a guide in determining the right communication strategy to be implemented in Surakarta. There are environment-scan stages that can analyze the behavior of Surakarta people who are happy to get service and combined with managing stakeholders and the purpose of communication strategy, so that the direction of the appropriate communication strategy can be determined, namely communication strategies based on close relationships. David Fleet stated in his theory about Strategic Communication planning that "Your environmental scan is about looking externally at what other people are doing and saying" [6]. It means that we must always pay attention to customer behavior before implementing a strategy. According to Littlejohn and Foss (2011) in Theories of Human Communication that relationships (relationships) are conversations that relate and create communication contexts as a place of communication and is a pattern formed from a conversation. The shape of a relationship varies greatly from time to time depending on the comfort and place when communicating, the level of difficulty when communicating. Changes when making this relationship play an important role in influencing the relationship itself. Differences in relations and changes in relations from the side of communication science, where the formation of a pattern of interaction between humans and the composition of responsive behaviors that change [11]. In this case the intention that the place and comfort in communication greatly affect the relationship in communication.

Third, by implementing communication strategy with 3 stages, namely finding, growing and keeping can form close relationships which cause increasing performance sales. Good performance is the effect of repeat buying and advocacy from customer who are very satisfied with the services provided by the Garuda's frontliner. This communication strategy is very 
effective if supported by social media, because the effects of advocacy and word of mouth marketing can lead to cross-regional purchases from other cities and it need the media to cummunicate. The results of this study the effect of this communication strategy, branch office Surakarta can record the high performance: sales achievement in 2018 reached USD $33,656.8804$, growth $20 \%$ from the previous year and reached the target of $118 \%$, and records profit from flight route Surakarta to Jakarta VV at USD 545,397. Customer satisfaction depends on the quality of the service product. According to Claudio Alvarez and Suzan Fournier that relationship are stronger when the brand ( service, Communication strategy ) contributes to or reflects the consumers's sense of self. Relationship quality which involves relationship dimensions such as intimacy, partner quality wihch give impact to buying behavior. [12] In this case what is meant by "quality" is "compatibility in meeting the needs of the customer" [13]. If the frontliner provides quality service that meets the expectations of the customer, so that the customer feels satisfied and will become a customer for life and generate revenue for the company [14].

\section{CONCLUSION}

The purpose of this study is to explore the strategy communication carried out by the Garuda Indonesia Branch Office Surakarta. This communication strategy consists of first, finding stage, this phase is orientation between customer and frontliner. The frontliner must be able to do first impression in the hearts of his customers so they will come back to do "repeat buying" at the Garuda Indonesia Branch Office Surakarta; second, keeping, in this phase the process of retaining customers and strengthening relationships communicates with customers. The behavior of the customer in this phase is usually no longer coming to the Garuda Indonesia's office, but only using WhatsApp media in communicating with the frontliner in booking tickets, changing schedules or making their complaints, and they do when and wherever they are; third is growing, where in this phase developing and growing customers. This can be done by forming customer loyalty by fulfilling their needs so that they can satisfy them, so they can advocate and do word of mouth marketing to others for Garuda's services. The impact of repeat buying and advocacy on other people will increase sales of Garuda products.

Referring to the results of this study, the theoretical implications that can be explained are related to the study of the communication strategy is implemented by frontliner of the Garuda Indonesia Branch Office Surakarta. In particular, how the frontliner at the Garuda Indonesia Surakarta can implement the communication strategy in providing its services. This communication strategy is a reflection of Garuda Indonesia's corporate value that applied and adapted to the character and behavior of consumers in Surakarta who are very happy to be served politely. In conducting this communication strategy frontliners apply the FKG strategy (Finding, Keeping, Growing), which in its application requires committed militancy and loyalty by frontliner of the Garuda Indonesia branch office Surakarta. In the application of communication strategies at every momentum when communicating to create comfort in communication so as to create a family relationship between frontliners and consumers. In this study, researchers used communication strategy theory consisting of communication orientation and conformity orientation from Mary Anne Fitzpatrick. Researchers found that family communication has several phases of finding relationships, keeping keeping and developing relationships. And if these phases are carried out consistently and strictly, they will be able to support the objectives of the company. Apart from that the orientation of conformity is also very important in realizing a family relationship in communication, because between 
frontliners and consumers are guided to be able to balance the role of each individual in order to find harmony and understanding.

Practical Implications, For practitioners and academics, this paper can be used as a reference to increase the knowledge and understanding of communication strategy of Garuda Indonesia branch office Surakarta. This communication strategy is a new strategic phenomenon that emphasizes closeness in interacting between frontliners and consumers. This is not necessarily possible in other branch offices because it requires high commitment and patience and coordination of each individual frontliner in the implications of the strategy.

In the digitalization era, the use of social media is used as well as a supporting tool in communication strategy, considering that currently everyone can connect in real time, even though they are in another city or country, they can still communicate with the Garuda's frontliner in conducting transactions for reservation and ticketing.

\section{REFERENCES}

[1] H. Kertajaya, Entrepreneurial Marketing, Compass \& Canvass, Jakarta: PT.Gramedia Pustaka, 2017.

[2] H. Kertajaya, Planet Omni, The New Yin Yang Of Business, Jakarta: PT.Gramedia Pustaka Utama, 2018.

[3] Suharto, Manajemen Strategi Perusahaan Penerbangan, Bogor: IN MEDIA, 2014.

[4] J. T. Wood, Komunikasi interpersonal, Jakarta: Salemba Humanika, 2013.

[5] Cavanaugh, "Consumer Behavior In Close Relationships," ScienceDirect, Elsevier, vol. 10, no. 2016, pp. 101-106, 2016.

[6] D. Fleet, Strategic Communications Planning, California: Creative common, 2008.

[7] J. Joireman, “Editorial Overview Consumer Behavior,” SicenceDirect, Elsevier, vol. 10, no. 2016, pp. iv-vii, 2016.

[8] N. D. warsihantari dan I. Ngurah Putra, "Airasia Crisis Communication Strategies and malaysia Airlines : a Content Analysis,” Jurnal komunikasi ISKI - researchGate, vol. 03, no. 01, pp. 18-27, 2018.

[9] R. Zhang, "Research On Shaanxi Brand Communication Strategy Under The New Media Environment," dalam 5th International Conference On Economics, Management and Humanities, Bangkok, 2019.

[10] J. W. Creswell, Research Design Pendekatan Metode Kualitatif, Kuantitatif, dan campuran, Yogyakarta: Pustaka Pelajar, 2016.

[11] S. W. L. john dan K. A. Foss, Theories Of Human Communication, Long Grove: Waveland Press, Inc, 2011.

[12] S. F. Claudio Alvarez, "Consumers' Relationships With Brand," ScienceDirect, vol. 10, no. 2016, pp. 129-135, 2016.

[13] P. Kotler, Manajemen pemasaran edisi 13, Jakarta: Erlangga, 2009. 14

[14] K. Saddhono, "Language and superdiversity: Indonesians knowledging at home and abroad. By Zane Goebel." Soc. Stu. vol. 12 no.1 pp. 113-118, 2018 